This item was submitted to Loughborough's Research Repository by the author.

Items in Figshare are protected by copyright, with all rights reserved, unless otherwise indicated.

\title{
The effects of board structure on corporate performance: Evidence from
}

\section{East African frontier markets}

PLEASE CITE THE PUBLISHED VERSION

https://doi.org/10.1016/j.ribaf.2020.101222

PUBLISHER

Elsevier

VERSION

AM (Accepted Manuscript)

\section{PUBLISHER STATEMENT}

This paper was accepted for publication in the journal Research in International Business and Finance and the definitive published version is available at https://doi.org/10.1016/j.ribaf.2020.101222.

\section{LICENCE}

CC BY-NC-ND 4.0

\section{REPOSITORY RECORD}

Guney, Yilmaz, Ahmet Karpuz, and Gabriel Komba. 2020. "The Effects of Board Structure on Corporate Performance: Evidence from East African Frontier Markets". Loughborough University.

https://hdl.handle.net/2134/12204989.v1. 


\title{
The Effects of Board Structure on Corporate Performance: Evidence from East African Frontier Markets
}

\author{
Yilmaz Guney* \\ Business School, University of Hull, UK \\ y.guney@hull.ac.uk \\ Ahmet Karpuz \\ School of Business and Economics, Loughborough University, UK \\ A.Karpuz@lboro.ac.uk \\ Gabriel Komba \\ School of Business, Mzumbe University, Tanzania \\ gkomba@mzumbe.ac.tz
}

\begin{abstract}
The effectiveness of the well-known corporate governance practices may not be universal due to fundamental differences in the environments under which firms operate. By using hand-collected data from all the non-financial firms listed on the unexplored East African frontier markets (i.e., Kenya, Tanzania and Uganda), we examine the effect of board characteristics on the performance of firms. Our results show that board size has a negative and significant effect on firm performance. The presences of foreigners and civil servants on the board play positive roles on financial performance, where the agency and resource dependence theories apply. Further, we find that board members with higher education also contribute to firm performance. These findings still hold when we consider the 2008-2009 financial crisis period. Overall, we show that in a business climate where ownership is largely dominated by few shareholders, the conventional governance mechanisms do not work effectively.
\end{abstract}

Keywords: Corporate Governance; Board Attributes; Frontier Markets; Agency Theory; Resource Dependence Theory.

JEL Classification: G32; G34.

* Corresponding author: Business School, University of Hull, HU6 7RX, Hull, UK. Tel: (+44) (0) 148246 3079. Fax: (+44) (0) 1482463492. 


\section{Introduction}

The literature on internal corporate governance mechanisms and firm performance has persistently been focusing on the developed capital markets. Studies that have explored this topic include Demsetz and Lehn (1985), Demsetz and Villalonga (2001), Cui and Mak (2002), Denis and McConnell (2003), Hillman and Dalzageniel, (2003), Daily et al. (2003) and Nicholson and Kiel $(2007)^{1}$. In the recent times, however, frontier equity-markets (FEMs) have surfaced as eye-catching investment destinations attracting the interest of a wide range of stakeholders, including regulators, academicians and both retail and professional investors (Nellor, 2008; Berger et al., 2011; IMF, 2011; FTSE, 2014). The main reasons for the growing interests despite the higher risks is that FEMs provide greater returns potentials and they are uncorrelated with other international markets. Thus, they provide further opportunities for diversification (Girard and Sinha, 2008; IMF, 2011). Despite these benefits, the investment dynamics in these markets are not well understood. In other words, the traditional investment considerations may not be relevant in the FEMs environment which is essentially different from that of developed markets. Clearly, this suggests that there is a need for an analysis of FEMs to figure out whether they fit into the conventional academic thinking and research framework. This study contributes to fill this gap by examining the impact of selected board of directors $(\mathrm{BoD})$ variables on the corporate performance of the listed firms in the East African (EA) FEMs.

Except for the Nairobi securities market (NSE), stock exchanges in the rest of the East African Community (EAC) member states were established following the structural reform programs and extensive financial systems liberalization of the mid-1990s. These programs were motivated by the support from development partners, including the multilateral institutions - the International Monetary Fund (IMF), World Bank (WB), and bilateral donor countries. It is during this period of economic reforms that these countries also embarked on the privatization of the state-owned enterprises (SOEs), most of which had unsatisfactory economic performance. Although

\footnotetext{
${ }^{1}$ See Yamahaki et al. (2016) for corporate governance issues in emerging markets, i.e., Brazil and South Africa.
} 
privatizations were expected to be carried out through the stock exchanges, that is, the sale of shares to the public to spread ownership, only a small number of the companies ended up being listed. One of the reasons for this was that, in many cases, governments chose the private or trade sale approach; whereby shares were sold to the "core or strategic investors". We use all the listed non-financial firms (hence, the population rather than a sample) from Kenya, Tanzania, and Uganda in our analyses.

A strategic investor is usually a large multinational company that has a long-term strategic focus on an undertaking. Since most of these SOEs were in financial difficulties, the governments preferred to sell them to strategic investors who would turn them around. For example, they could inject in the businesses more capital, provide quality management, develop workforce capacity in terms of knowledge and skills, and improve technology and customer service, to mention a few. As a consequence of selling to the strategic investors, a few big shareholders own a large proportion of the shares of the privatized SOEs. This is also the case with most of the other companies listed on the EAC exchanges which were not previously state owned. Thus, there are restricted shares left available in the market for the other investors to trade freely (Dahlquist et al., 2003). This can explain why these frontier markets are not vibrant since they have a very small investor base with very limited number of listed corporations, suffer from infrequent trading and therefore they are illiquid, and lack adequate supply of securities. Although the studies based on the frontier markets tend to suffer from the small sample bias, such studies can still be useful as analysing these relatively unexplored markets might yield findings that are relevant to the policy makers, investors and constitute a base for future research when data becomes more available and sample size gets larger.

Despite these and other defining characteristics, regulatory authorities in the EAC region are striving to improve the quality of institutional and policy frameworks to create a conducive investment climate. Crucially, the regulators are aiming at improving the effectiveness of corporate governance by encouraging listed companies to adopt and implement best practices to meet the standards needed to attract the attention and capital flows from a diverse investor base (Cuomo et 
al., 2016). However, these best practices or codes were designed in advanced economies and may not be applicable to underdeveloped markets.

There is evidence that the EA countries compare consistently unfavourably to other countries in the scores of key areas of corporate governance. For example, the World Economic Forum reports (WEF, 2012, 2013) reveal that the ranking of the global competitive index $(\mathrm{GCI})^{2}$ for the EA countries is very low (see table 1). One would therefore expect to observe a wide inter-firm variation in governance behaviour in these markets (Shleifer and Vishny, 1997). Black et al. (2017) raise similar concerns for the emerging markets. Under such circumstances, the literature indicates that corporate governance practices should matter more when investors are making investment decisions (La Porta et al., 1999, 2000; Black, 2001; Klapper and Love, 2004; Morey et al., 2009).

Our study is also motivated by the deliberate efforts undertaken by the regulators to directly or indirectly improve corporate governance practices in the EA markets in order to attract foreign investors from developed countries to invigorate the markets by bringing in more capital and reduce cost of equity (Hai et al., 2018). The assumed importance of the strategic investors or large private shareholders on improving the performance of listed firms is another motivating factor for our study. This ownership structure makes the implementation of the best corporate governance practices in EA frontier markets questionable (La Porta et al., 1999; Gibson, 2003). In particular, this kind of ownership dominance may result in failure by the BoD to execute properly their functions. A wellfunctioning board is responsible for, first, mitigating the agency costs, and reducing the cost of capital (Fama and Jensen, 1983; Hillman and Dalziel, 2003; Kumar and Zattoni, 2017). Second, the BoD is expected to provide advice and key resources to the company by linking it to the external environment (Daily et al., 2003). In addition, the board has the duty to ensure that the firm complies

\footnotetext{
${ }^{2}$ Since 2005, the World Economic Forum has been publishing annually the Global Competitive Report (GCR) which ranks countries based on the Global Competitive Index (GCI). The GCI is a comprehensive tool that measures the microeconomic and macroeconomic foundations of national competitiveness. The World Economic Forum (2012, 2013) defines "competitiveness as the set of institutions, policies, and factors that determine the level of productivity of a country. The level of productivity, in turn, sets the level of prosperity that can be reached by an economy. The productivity level also determines the rates of return obtained by investments in an economy, which in turn are the fundamental drivers of its growth rates".
} 
with applicable laws and regulations (Denis and McConnell, 2003). Since these two functions are not mutually exclusive and that in most cases, large owners have more representatives on the boards; we argue in this paper that this ownership characteristic in EAC exchanges may impact the functioning of the BoD. That is, the boards may be focusing more on monitoring the behaviour of managers to ensure that they operate in the best interest of the core or big shareholders.

Related to our study, Outa and Waweru (2016) investigate the impact of corporate governance standards (i.e., corporate governance guidelines introduced in 2002 by Kenya) on firm performance and value in Kenya. They document that corporate governance compliance has positive relation with firm performance and value. Our study differs from theirs since our main focus is the association of board structure (i.e., board size, foreigners on the board, senior civil servants or politicians, and academic qualifications) with firm performance. Our paper also documents evidence for the relation between ownership structure (i.e., foreign ownership, institutional ownership and ownership concentration) and financial performance. It should further be noted that Pillai and AlMalkawi (2018) examine firms in Gulf Cooperation Council (GCC) countries and Mertzanis et al. (2019) study firms in the MENA region regarding the corporate governance and performance link.

To the best of our knowledge, other than the aforementioned similar papers, there is no study that has directly investigated whether the board structure in frontier markets affects corporate outcomes. This research, therefore, employs a long span dataset of listed companies from the three EA countries ${ }^{3}$ to address the following core question: do the board structures of firms listed in the EA frontier markets affect firm performance? To answer this question, we use a hand-collected data set on all the listed non-financial firms from the stock markets of Kenya, Tanzania, and Uganda over the period of $2000-2013$.

\footnotetext{
${ }^{3}$ These are Kenya, Tanzania and Uganda. We chose these countries because they are in the process of establishing a regional exchange with operations in each of the partner states. The regional integration initiative began in 1997 with the establishment of the East African Securities Regulators Association (EASRA). During that time Rwanda and Burundi did not have stock markets. The implementation progress is promising, as the common market is likely to take off within a few years (EASEA, 2015).
} 
Our results briefly show that board size negatively affects the operating performance of listed companies. The findings further indicate that the presence of foreigners and civil servants (or politicians) on the board has significant and positive associations with firm performance. ${ }^{4}$ Further, the level of academic qualifications has positive impacts on firm performance. The study also finds that there is a positive association between ROA and ownership by institutional investors and the largest shareholder. Moreover, foreign ownership has no significant relationship with ROA.

We also investigate if our findings are affected by the 2008-2009 financial crisis. The recent financial crisis has been viewed as an external shock for many countries including the EA region and several studies have examined its impact on corporate governance for different countries. For instance, using a sample of European firms from 26 countries, Van Essen et al. (2013) document evidence that small board size harms firm performance during the 2007-2009 financial crisis. Liu et al. (2012) also show that there is a U-shaped relation between the financial crisis period and ownership by large shareholders in China.

Following this literature, we analyze how the recent financial crisis affects the impact of the board structure on corporate performance in EA frontier markets. We show that our findings still hold when we take the potential effect of the recent financial crisis into account in our analysis. We document that there is no significant difference between the crisis and non-crisis periods in terms of the impacts of board structure (i.e., board size and board diversity) on performance. The relation between ownership structure (i.e., foreign ownership, institutional ownership and ownership concentration) and performance also does not differ during the crisis period.

We contribute to the literature by studying the association of the corporate outcomes with board structure in the East African frontier markets; our research contributes to the growing literature investigating the importance of board characteristics in firm performance in the frontier markets (e.g., Outo and Waweru, 2016).

\footnotetext{
${ }^{4}$ A civil servant is a public servant. According to the Public Service Act, Cap. 298 of the United Republic of Tanzania, and Standing Orders for the Public Service, 2009, a "public servant" means a person holding or acting in the public service office. Public service as defined in the public service management and employment policy amongst others include the service in the civil Service; the political Service; and the local government service.
} 
Our analyses provide further salient insights: for instance, we show that in a business climate where corporations are held by large shareholders, the known board characteristics in developed markets do not work effectively. Following the literature (e.g., Ahrens et al., 2011; Liu et al., 2012; Van Essen et al., 2013), we consider the effect of the 2008-2009 global financial crisis and provide evidence that this crisis does not have a significant impact on the relation between the board characteristics and corporate performance in EA frontier markets.

The paper proceeds as follows. Section 2 presents a brief overview of the corporate governance legislations of the three EA countries included in the study. We provide the literature review and development of the research hypotheses in section 3. Section 4 describes the data and sample construction and methodology. Section 5 presents and discusses our empirical findings. Section 6 concludes the paper.

\section{Corporate governance laws and codes in the EA markets}

The EA markets have opened to the international investment community. Consequently, improvement of the corporate governance practices to be compatible with those in developed economies has been directly or indirectly high in the agenda. However, it is well known that there are many hindrances in Africa that frustrate the efforts to improve governance mechanisms. By Western economies' standards, the financial markets in Africa are considered as being underdeveloped. Rossouw (2005) also points out that the legal and regulatory systems in many African countries are not properly functioning. This includes weak protection of shareholder and creditor rights, and lack of enforcement of legal rights by the judicial system (Wanyama et al., 2009; Claessens and Yurtoglu, 2013). Moreover, these countries lack the overall disclosure, transparency and market discipline related to better governance practices to the extent of deterring more private companies to list in the stock exchanges that exist. Furthermore, the governments are perceived to be highly bureaucratic and corrupt (Kaufmann et al., 2011).

The three countries (i.e., Kenya, Tanzania and Uganda) are former colonies of the United Kingdom and are members of the Commonwealth. This means that their legal and judicial systems 
are based on British common law. In addition, the Kenya's capital market development is more advanced compared with her counterparts. In order to facilitate the regional integration agenda, therefore, the legal and regulatory frameworks in Tanzania and Uganda, do not deviate too much from that of Kenyan securities law (Dmitry et al., 2008). Moreover, like other African countries, the EAC member states governance approaches heavily rely on the OECD principles, the South African King's report, and the commonwealth Association for corporate governance pronouncements (Rossouw, 2005; Wanyama et al., 2009; Waweru, 2014). The next subsection discusses the institutional setting of each of the three countries in relation to corporate governance.

\section{[Insert Table 1 here]}

\subsection{Corporate governance in Kenya}

The revised Companies Act, 2009 is the main source of law on corporate governance in Kenya. The Act stipulates the basic structure and primary rules of running companies. It also contains provisions that establish the position of director, duties, and matters-related shareholders' protection. Apart from the Companies Act, Waweru (2014) and Barako et al. (2006) points out that Kenya produced and published her first national code, the Private Sector Corporate Governance Trust (PSCGT) in 2000. These guidelines were to be adopted voluntarily, by implementing the “comply or explain" enforcement concept. The key recommendations of the PSCGT among others, included; companies to establish audit committees composed of non-executive directors, improvement of the quality of financial reporting, and extending the scope and duties of external auditors.

According to Barako et al. (2006), the PSCGT contributed substantially in the development of the guidelines on good corporate governance practices by public companies that were issued by the Capital Market Authority (CMA) in 2002. Implementation of these guidelines was mandatory for all listed companies in Kenya. The guideline mainly deals with issues related to the board and the role of good corporate governance on performance. Others include; shareholders value maximization and rights (Barako et al., 2006; Gakeri, 2013; Waweru, 2014). Moreover, the Nairobi 
Stock Exchange provides and maintains the listing requirements for all listed companies. In addition, statutes dealing with professional bodies like lawyers, accountants, and public secretaries also have an impact on standards of good corporate governance (Musikali, 2008).

\subsection{Corporate governance in Tanzania}

There are two main legislations that deal with corporate governance issues in Tanzania. The Companies Act, 2002 contains several provisions on the statutory duties and responsibilities of directors. The provisions are in line with the duties prescribed under common law. The Capital Market and Securities (CMS) Act, 1994 (as amended by Act No. 4 of 1997), read together with its regulations and rules; provide the foundations for corporate governance practices. The CMS Act, 1994 among other things, regulates access to business, conduct of business, and disclosure by both investee companies and market operators. The regulations are designed to ensure transparency, stability, and integrity as well as investor protection.

The corporate governance system of Tanzania can be seen as a hybrid version of the marketbased approach. In addition to the statutory rules of corporate behaviour contained in the company law, Tanzania developed her own national code on corporate governance in 2002 (Kibola, 2002; The Committee, 2001; Kaduma, 2002). The recommended "Guidelines on corporate governance practices by public listed companies in Tanzania" among other things, emphasizes the need for boards to ensure that their entities comply with all good governance practices, relevant laws and regulations, and auditing and financial reporting standards (Kibola, 2002). The Bank of Tanzania (BOT) issued guidelines for boards of directors of banks and financial institutions in 2008. The guidelines stipulate the duties and responsibilities, composition and conduct, and the committees of the board.

\subsection{Corporate governance in Uganda}

The corporate governance reforms in Uganda have gone through several steps. In 1993, the Government of Uganda enacted the Public Enterprises Reform and Divestiture (PERD) Statute to 
operationalise the Government's PERD Statute (1991) and its Action plan. PERD targeted to privatize more than 100 SOEs (Wanyama et al., 2013). Then, in 1996 the Capital Markets Authority (CMA) of Uganda was established following the enactment of the Capital Markets Authority Act, 2000 (Revised). In exercising its powers, the CMA issued the Capital Markets Corporate Governance Guidelines, 2003. In section 2 of Part I of the guidelines, it is stipulated that the CMA developed the guidelines as a minimum standard for good corporate governance practices by public companies and issuers of corporate debt in Uganda. Among other relevant issues, the guidelines cover best practices related to the board composition, separation of the roles and responsibilities of the chairperson and the Chief Executive, rights of shareholders and the roles of audit committees. These guidelines, however, are not mandatory.

Moreover, the Institute of Corporate Governance of Uganda (ICGU) was incorporated in 1998, and its membership is open to both corporate entities and individuals. In 2001, ICGU published the recommended guidelines for corporate governance. These guidelines are not mandatory, but they contain the basic framework for corporate governance such as best practices related to boards of directors, shareholders, regulatory bodies, investors and other stakeholders. However, ICGU recommends them to be used by all corporations in Uganda regardless of their form of ownership or size. This is because both public and private sectors are equally affected by corruption, bad leadership, public mistrust and lack of transparency and integrity, to mention a few (Wanyama et al., 2013; Liu et al., 2019).

In addition, the Uganda Securities Exchange listing requirements direct issuers to comply not only with the listing rules of the exchange but also with the laws and requirements of various regulatory and supervisory authorities (e.g. the CMA). The Central Bank, on the other hand, through the Financial Institutions Act (FIA), 2004, has made corporate governance compulsory for financial institutions. The FIA sets the minimum number of board members and requires all directors to be fit and proper persons. The Act provides for disclosure requirements, establishment of audit committees and duties of the internal and external auditor to the Central Bank, among others. 


\section{Related literature and hypotheses development}

\subsection{Board structure}

The firms listed in the EAC exchanges are expected to be managed professionally to attract investor confidence and safeguard the public's interest. With this hindsight, most of these firms have been appointing BoD with certain attributes. The current study examines two board characteristics, namely, board size, and board diversity. We subsequently develop the theoretical associations between these characteristics and firm performance. Table A1 in the Appendix defines all variables.

\subsection{Board size}

The size of the $\mathrm{BoD}$ is one of the important determinants of its effectiveness, although it is not clear as to what size is optimal. Arguments in favour of small board size indicate that it is quite difficult to organize and coordinate large groups of people. It is also argued that when the size of the board is large it increases costs to the firm, and lengthens the time to resolve issues due to squabbles (Hackman and Morris, 1975; Cheng, 2008). Other scholars assert that the size of the BoD depends on purposes it is chosen for (Yermack, 1996; Lipton and Lorsch, 1992; Hermalin and Weisbach, 2003; Alves et al., 2015). According to the agency view, smaller boards are more effective if the firm needs the BoD for monitoring roles (e.g., Pillai and Al-Malkawi, 2018). On the other hand, the resource dependence theoretical perspective suggests that larger boards are useful when the firm seeks quality of advice (Dalton et al., 1999; Coles et al., 2008).

However, it is argued that the breadths of services offered by small boards are limited. This may manifest, for example, when small boards fail to monitor managers effectively because they have fewer members to allocate to different committees (Yermack, 1996; Lipton and Lorsch, 1992; Klein, 1998, 2002). One can therefore suggest that big firms that have complex operational structures and depend on external sources of financing should require large boards, for more effective discharge of both the monitoring responsibility and provision of advising role (Dalton et al., 1999; Anderson et al., 2004). Most of the listed firms in the EA exchanges do not have complex 
operational structures, but they still have higher chances of growing and expanding even across boundaries. It is thus hypothesized for our sample firms that:

Hypothesis 1: Board size positively affects firm performance.

\subsection{Board diversity}

Despite receiving considerable attention, empirical evidence concerning the benefits of board diversity provides mixed results. For instance, Watson et al. (1993) contend that heterogeneous boards have long-term impact on a firm's objectives; Pelted et al. (1999) report that diversity has detrimental effects on performance. Zona et al. (2013) document that diversity is less important in larger firms for innovation. Majority, however, concur with the view that diversity plays an important role in shaping the functioning of the board. It creates different culture, new mind set, equality and fairness, enhance competence profile, and new perspectives on the boardroom (Rose, 2007).

Similarly, other studies examine the diversity of directors in terms of international versus local profiles. Consistent with the resource dependence theory, the board with a combination of local with foreign members may benefit from a number of opportunities. These include attracting capital from foreign investors, market expansion to foreign countries, and exposure to skills and expertise that is not available locally (Oxelheim and Randøy, 2003). As Fairchild et al. (2014) posit, the presence of foreign members on the board serves as a means of breaking away information asymmetries and monitoring gap that exist between the domestic and foreign investors. Gulamhussen and Guerreiro (2009) found that there is an association between BoD with foreign members and reduction in operating and total costs. They attribute this observation with the enhanced monitoring role and the influence of the foreigners on the adoption of efficient strategic and operational practices. Therefore, we conjecture that:

Hypothesis 2a: Foreigners on the BoD have a positive impact on firm performance. 
The attractiveness of an individual to be appointed as an outside member of a BoD is determined by their depth and breadth, and human and social capital, which is critical to discharging the board's resource provision function (Hillman and Dalziel, 2003; Daily et al., 2003; Hillman, 2005). It is common to find listed companies on the EA stock markets having appointed currentlyserving or retired senior civil servants and/or politician as outside directors on their boards. From resource dependence perspective, placing government officials on the board aims to capitalize on valuable non-business perspectives that they bring to an organization. These include their networks and linkages to other government officials and decision-makers, legitimacy to the firm, expertise, counsel and advice about the public policy environment (Pfeffer, 1973; 1972; Zona and Zattoni, 2007; Lester et al., 2008; Guo, 2019). They can also be used to influence the shaping of policies, laws and regulations, and even its enforcement (Berglof and Claessens, 2004).

The institutional theory, on the other hand, suggests that the appointment of this kind of outside directors could be seen as a bandwagon effect. ${ }^{5}$ This is because the majority of these officials have built their internal career in traditional government bureaucratic systems and lack business acumen, they may not be necessarily effective in monitoring and controlling management thus fail to improve firm performance (Peng, 2004; Muth and Donaldson, 2002). In partially SOEs, directors may be appointed by the state not on merit but purely on political grounds (Rossouw, 2005; Wanyama et al., 2009). Past research, however, suggests that firms with government officials on their boardrooms perform better than those without (e.g., Hillman, 2005). This is consistent with Pfeffer (1972) who contends that creation of linkages with main sources of external dependence helps to reduce risks and uncertainty, which in turn impacts firms' operations. Since the government is the key source of uncertainty for firms in terms of policy and regulations, companies that choose to appoint politicians on boards, can avoid some transaction costs such as those of securing information

\footnotetext{
${ }^{5}$ Please see Judge et al. (2010) for institutional theory discussion.
} 
about political decisions and ultimately improve performance (Hillman, 2005; Lester et al., 2008). Hence, we posit that:

Hypothesis 2b: Civil servants or politicians on the BoD have a positive impact on firm performance.

As stated earlier, the attractiveness of an individual as a director candidate is determined by a set of unique attributes and resources that they can bring into the organization (Hillman and Dalziel, 2003; Lester et al., 2008; Guo, 2019). However, how the education level of the board members influences firm performance is not confirmed. Rose (2007) finds educational qualification has no impact on firm performance and further contends that since the work carried out on the boards is not discipline specific, a university degree or equivalent skills may be sufficient to understand information received from the management. Similarly, Anderson et al. (2004) do not find significant difference in monitoring among academics and other occupations. On the contrary, Murphy (2007) and Anderson et al. (2011) found that educational qualification had a positive impact on firm performance. We expect that boardrooms composed of directors with different education attainment qualifications can benefit from the diversity of individuals' knowledge, expertise, skills and cognition abilities (Anderson et al., 2011). Directors with higher levels of education are assumed to be more adaptive and innovative. Possession of these qualities may in turn create value to the firm. Thus, we expect that:

Hypothesis 2c: Directors with MSc and PhD degrees on the BoD enhance firm performance.

\section{Data and methods}

\subsection{Data sources}

This study draws its population from all the non-financial firms primarily listed on the three frontier stock markets in the EA countries during 2000 to 2013 , to match with when the first equity was listed and floated in the Uganda Stock Exchange (USE). To address the widely documented problem of unavailability of data in many African stock markets; we used the websites of each stock exchange in the region to obtain the list of all quoted companies. From this initial sample, we 
excluded all firms operating in the banking and financial related sectors. The reason is that their accounting treatments of certain line items in financial statements are different. Moreover, they have additional requirements and governance structures that are regulated by monetary authorities. In addition, the omission of financial firms is consistent with the analyses done in similar previous studies. Our final sample consists of 47 firms drawn from seven industries as classified by the NSE. This includes both active and failed or other companies that have left the market, thus making our data set survivorship bias free. Out of these, 33 firms are listed in the NSE, the largest stock market in the region. The stock markets of Tanzania and Uganda are very small, with nine and four companies in the sample, respectively. In total, we have 482 firm-year observations (see table 2).

\section{[Insert Table 2 here]}

Data for ownership and board characteristics were collected manually from the published annual reports of the respective companies. The reports, however, were obtained from various websites, including the company's own. Annual reports for all companies listed on the Dar es Salaam Stock Exchange (DSE), for example, were downloaded from the exchange's website, http://www.dse.co.tz. The annual reports for companies listed on the NSE for the years 2003 to 2012 are available for downloading on Capital Markets Authority (CMA) of Kenya's website, http://www.cma.or.ke.

We also used the African Financials website (http://www.africanfinancials.com). ${ }^{6}$ This website boasts itself as the world's largest portal of free African investor documents. It has a large collection of annual reports for listed companies in Africa. Despite using different websites, yet still there were some missing annual reports for some years for some companies. We did not drop off firms with missing information from the sample. Instead, we retained whichever part, before or after the gap, that had many consecutive observations.

\footnotetext{
${ }^{6}$ Data collection in these markets is extra challenging because of the problem of obtaining annual reports. In some years, even the listed companies themselves do not have their annual reports on their websites.
} 
Data for foreign exchange rates and accounting related variables, on the other hand, were obtained from the Bloomberg database. In cases where some data were missing, we collected them manually from the published annual reports to fill the gaps. It is important to note, however, that the annual reports are prepared in local currency, while the information downloaded from Bloomberg was in US dollars. To put them in a common currency, we converted the local currency data into US dollar using the yearly average foreign exchange rates.

\subsection{The variables}

\subsubsection{Measuring firm performance}

The concept of corporate performance has always been on the financial context and there exist several measures (Denis and McConnell, 2003). Accounting-based measure is, however, one of the most important measures used to evaluate overall aspects of a firm's performance. The accounting proxies portray the historical operating performance of the company to generate profits in terms of the capital employed. That is, they indicate the extent to which the agents have effectively and efficiently utilized the resources entrusted to them. In this study, we use the return on assets (ROA) as a proxy for financial performance.

\subsubsection{Board structure variables}

To provide an empirical analysis in order to test the hypotheses discussed above we use the following variables: the size of the corporate board, the fraction of foreigners on the board, the proportion of the senior civil servants or politicians on the board, and the level of academic qualification of board members (i.e., the fraction of directors having postgraduate degrees).

\subsubsection{Control variables}

First, as the ownership structure variables as controls, our study includes foreign ownership, institutional ownership, and also ownership by the largest shareholder. In his section, we discuss these variables and related literature. 
The reason why adherence to the best practices has become a top item on the agenda is to enable listed companies in EA exchanges to be able to attract both domestic and foreign investors. Increased participation of foreign investors is expected to enhance not only liquidity in the markets but also values of the firms. In addition, when foreign investors participate, they are more likely to perform arms-length monitoring through their board representatives (Oxelheim and Randøy, 2003; Gulamhussen and Guerreiro, 2009). Hai et al. (2018) document that foreign shareholders help reduce cost of equity and increase firm performance. Moreover, investors from overseas where companies are vigorously governed are experienced. They are better positioned to influence key institutions and regulators to take actions to enhance governance practices. Thus, we expect foreign ownership to be positively associated with firm performance.

Institutional investors normally hold significant proportion of the share capital of companies compared to other investors in countries where ownership is dispersed (Ozkan, 2007). Accordingly, the presence of institutional investors may be instrumental in ameliorating the agency problem. Firms with substantial participation by institutional investors are expected to pursue activities that are aligned with creating shareholders' wealth. Like other block holders, institutional investors are better positioned to improve monitoring by exercising their powers to remove managers who act against their interests or basing on managerial performance. This is possible because they are wellinformed and have the tools to acquire such a kind of information (Tong and Ning, 2004). They can also improve managerial accountability by increasing their representation as outsiders on the board (Mak and Li, 2001), or indirectly by withdrawing their stake in the firm (Gillan and Starks, 2005).

Empirical findings pertaining to the oversight role of institutional investors are rather mixed. Faccio and Lasfer (2000) analysed the monitoring role of pension funds in UK. They found that the role that institutional investor play in minimizing agency conflicts is weak. Furthermore, they reported no significant relationship between institutional ownership and firm performance. Tao et al. (2018) document evidence from Chinese public firms that casts doubt on the monitoring role of institutional investors. Cronqvist and Nilsson (2003) also found that the presence of institutional 
owners had no significant effect on firm value. Other authors including McConnell and Servaes (1990), Smith (1996), Ackert and Athanassakos (2003), and Mertzanis et al. (2019) on the contrary, reported that the control exercised by institutional owners has a significant and positive effect on firm performance. In the EA frontier markets, the largest shareholders own more than $50 \%$ of the issued share capital. The ownership by institutional investors, therefore, does not give them sufficient power to exert influence over the company's affairs. Given our unique sample, this presents an interesting case warranting a further investigation of the role that institutional investors play on firm performance. We expect that ownership by institutional investors has a positive impact on firm performance.

Some external governance mechanisms in frontier markets are underdeveloped or do not exist (e.g. hostile takeovers). The agency theory postulates that, in such a kind of environment, block ownership may be an important governance mechanism for monitoring the management (Shleifer and Vishny, 1997; Kumar and Ramchand, 2008; Kumar and Zattoni, 2014). Blockholders are active in mitigating the agency conflicts either directly by monitoring management performance (Mak and Li, 2001), or indirectly by withdrawing their stake in the firm (Gillan and Starks, 2005). The reasons why big investors have incentives to exercise the monitoring role are: the amount of investment they make is significant (Tong and Ning, 2004); they are more informed because they have the necessary resources to enable them access different information they need (Mak and Li, 2001), and more importantly, is the fact that the benefits of monitoring exceed the related costs.

Empirical studies on the relationship between ownership concentration and firm performance offer mixed results. Demsetz and Lehn (1985) find no significant positive relationship. Tam and Tan (2007) find a negative relation between ownership concentration and firm performance. Holderness and Sheehan (1988), Sarkar and Sarkar (2000),Khanna and Palepu (2000), and Mertzanis et al. (2019) largely support the notion that ownership concentration increases firm value. We, therefore, extend this logic of concentrated ownership, and expect that ownership by the largest shareholder is positively associated with firm performance. 
We now discuss the controls other than the factors pertaining to corporate ownership structure. Previous studies have shown that firm characteristics influence both firm performance and governance mechanisms in different ways. For example, Wintoki et al. (2012) argue that the scope and complexity of operations, as well as the monitoring costs and manager's private benefits are among the determinants of a firm's board structure. We, therefore, include several control variables that have been commonly used in literature in order to minimize the possible misspecification in our analysis (Tam and Tan, 2007; Black et al., 2012).

We include firm size, for several reasons. It may cause governance practices to change, e.g. board structure, due to the increased complexity of the firm's operations (Wintoki et al., 2012). Larger firms may perform better because they possess many resources to enable them to capitalize on the economies of scale. They are also more capable of adopting and implementing good governance systems, since they are well-equipped with the facilities. Similar to prior studies, such as Black et al. (2012) and Fairchild et al. (2014) we control for leverage, because firms with a high debt ratio may be financially constrained and should be less able to perform better. Moreover, debt providers may be motivated to provide close monitoring and hence pressurize the companies to adopt governance practices that best suit their interests. Performance is also related to the firm's profitability and growth prospects (Yermack, 1996; Black et al., 2012). We control for growth level since it may have a significant impact on both governance mechanisms and financial performance. For example, small boards may be more appropriate for high-growth firms because they facilitate fast decision making. Likewise, we include year, sector (as classified by the Nairobi Securities Exchange (NSE), see table 2) and exchange dummies in the analyses to reflect their influence on governance mechanisms and performance.

\subsection{The estimation methods}

Most of the corporate governance related data were collected manually. It was, therefore, important to examine the data for the presence of extreme observations that would unduly influence 
the empirical results before any analysis was conducted. The following variables; ROA, presence of senior civil servants on the board, the level of schooling, sales growth and leverage had observations that were unrepresentative of the studied population. The top and bottom $5 \%$ extreme values for these variables were thus winsorized to address the problem of outliers (see also Welch, 2004; Ammann et al., 2011). Winsorization of outliers is appealing because the data maintains its population features and ensures the findings can be generalized to the entire population (Hair et al., 2006).

Furthermore, we used histograms to examine the shape of data distribution for each variable visually. A normal curve was also superimposed on the distributions to assess the normality of the variables. The examination showed that the distribution of board size was non-normal. This necessitated a further normalization of these variables by logarithmic transformation. Our conceptual model is summarized as:

Performance $=f$ (board structure, control variables)

Using econometric notations, equation (1) can be stated as:

$$
y_{i, t}=\beta_{0}+\beta_{n} \sum B O D_{n, i, t}+\beta_{q} \sum C T R L_{q, i, t}+\varepsilon_{i, t}
$$

where $y$ represents the financial performance (ROA) of firm $i$ at time $t$; $B O D$ refers to the board structure components; CTRL is for the control variables including the ownership structure components; $n$ and $q=1, \ldots, N$ and $\varepsilon_{i, t}$ is the idiosyncratic error term. Given the dynamic nature and structure of the data, a panel data methodology was considered to be the most appropriate for carrying out the analyses as it addresses the heterogeneity concerns that exist between the firms and the explanatory variables (Bond, 2002).

To address the potential endogeneity concern, the study employs the two-stage least squaresinstrumental variable (2SLS-IV) method; and for firm-level heterogeneity we consider the randomeffects (RE) or the fixed-effects (FE) specifications where appropriate. According to Wooldridge (2009), if omitted variables are correlated with other variables in the model the FE estimator 
provides a means to control for or remove the effects of time-invariant differences (or unobserved effects) and thus mitigating the endogeneity problem (Yermack, 1996; Bai et al., 2004; Love, 2011). The RE estimator, on the other hand, assumes that the unobserved variables are uncorrelated with all observed variables. It, therefore, allows the effects of time invariant variables to be estimated in the model. However, we may need to specify all firm-specific effects having or not having influence on the predictors. In practice, this may not be possible and hence leads to omitted variable bias. Furthermore, the RE estimator assumes that the observed heterogeneity is uncorrelated with all independent variables. Our study uses the Breusch-Pagan test to decide if the data should be pooled in a panel format, i.e., whether RE is more appropriate than the OLS method. If pooling the data is appropriate, then we use the Hausman test to choose between the RE and FE methods.

It is well documented in the literature that it is practically difficult to identify valid and purely exogenous instruments in corporate governance and performance relationships. Some studies, such as Bhagat and Bolton (2008), and Wintoki et al. (2012), however, have treated board and ownership structures as endogenous variables and used their lagged values as instruments. Their idea is that current and previous period's governance simultaneously determines firm performance. Our study follows the same approach. It employs the Durbin-Wu-Hausman (DWH) (augmented regression) specification to assess whether the board structure regressors used throughout the study are endogenous.

The econometric literature points out that the IV/2SLS regression estimations are most biased and suffer from severe size distortions when the instruments are weak (excluded instruments only weakly correlated with included endogenous regressors). In the light of this, it is appropriate to initially examine the strength of the instruments. The test involves assessing the goodness-of-fit in the "first stage" regressions relating each endogenous regressor to the entire set of instruments. Accordingly, we adopt the Stock et al. (2002)'s criterion, which suggests that an F statistic greater than 10 makes inferences based on the 2SLS estimator reliable for a just-identified model. 


\section{Results and discussion}

\subsection{Descriptive statistics}

Table 3 presents the summary statistics from the full sample for the main variables used throughout the analysis. The firms have a mean (median) $R O A$ of $12 \%(9 \%)$. This value from the EA frontier markets is higher than that from the developed markets (see, for instance, Larcker et al., 2013; Lindemanis et al., 2019). This suggests that the firm profitability in EA frontier markets is higher than the profitability in developed markets. The average board size is 10 members, with a minimum of three and maximum of 22 . This is higher than recommended number of seven to eight members (Lipton and Lorsch, 1992; Jensen, 1993; Hermalin and Weisbach, 2003). It further shows that the representation of foreigners on the board averages $28 \%$ and the maximum proportion is $100 \%$. This level of participation of foreigners on corporate boards is something that should be expected. It is a reflection of the influence of the highly concentrated ownership, for both the privatized SOEs that were sold to strategic investors and other privately owned companies. These findings suggest that ownership by biggest shareholders is the primary governance mechanism of the EA listed companies. Alternatively, these results may reflect the fact that foreign board members bring certain skills and expertise that business operations in the three industries mentioned above need but are not available locally.

\section{[Insert Table 3 here]}

The proportion of senior civil servants or political leaders on the boards in table 3 is averaging $12 \%$ (maximum 50\%). For privatized SOEs, the board members represent the interests of the governments. For other public companies, the appointment of civil servants on their boards may be interpreted as a ploy to protect the businesses against political risks, but also for lobbying purpose. Table 3 also provides information about the level of education of the board members. It indicates that, on average, $35 \%$ (maximum 100\%) of the members have a master's degree or above. This may reflect that education qualification is an important attribute for appointments of board members. 
Table 3 further presents that on average (median), 50\% (51\%) of the total issued share capital is owned by the largest shareholder (big). This suggests that listed firms in EAC exchanges tend to have concentrated ownership. This observation is largely explained by the privatization strategies that governments in the EAC used. Since most of the SOEs were ailing when they were privatized, the governments were looking for investors who could turn them around by investing a significant amount of money in exchange of the company's issued shares. The same reason applies to the observed percentage of ownership by foreign investors in table 3 . That is, it reflects the effect of the economic reforms and the privatization across the EAC member states. The shares that the governments retained after the privatized SOEs were sold to local institutional (with mean $51 \%$ and median 63\%) and retail investors.

In table 4 we report the pairwise correlation matrix for the variables employed in the analysis. The purpose of examining this relationship is twofold. The first purpose is to identify the degree of interaction between the variables. We note several important observations. The correlation between measures of firm performance and firm size, and leverage is negative and strongly significant. Board size is negatively and significantly correlated with $R O A$. This relationship suggests that companies with large board size have lower current profitability.

\section{[Insert Table 4 here]}

Table 4 further shows that largest shareholder, foreign ownership, institutional ownership, proportion of foreigners on the board, proportion of members with masters or higher level of education and sales growth are strongly positively correlated with the proxy of firm performance. These findings validate our earlier assertions that if ownership is concentrated in the hands of few shareholders, there is close alignment of interest which ultimately affects firm value. Given the huge investment that they have put in these companies, largest investors are compelled to maintain a dominating voice in the company's strategies, policies and decisions.

The same applies to the foreign and institutional investors. That is, they may be influential in the monitoring and advisory roles which can help firms to avoid over-reliance on concentrated 
ownership (Young et al., 2008). The proportion of senior civil servants on the board has strong positive correlation with $R O A$. Consistent with the resource dependence theory, the findings suggest that the presence of government officials or politicians on the boards facilitates access to crucial resources the firms need to enhance operations and performance (Daily et al., 2003; Okpara, 2011; Hillman and Dalziel, 2003; Guo, 2019).

The second purpose of examining the correlations is to identify the presence of the multicollinearity problem in the data. According to Hair et al. (2006), high correlation that equals to 0.9 or above is an indication of substantial collinearity. The correlation between $R O A$ and prof is greater than this cut-off point and highly significant. This variable, therefore, was not included in the ROA regressions. The magnitudes of the correlation coefficients for the remaining variables indicate that there is no multicollinearity problem, which was also supported by the "VIF $<10$ " threshold.

\subsection{Effects of board structure on performance}

Table 5 presents the first set of regressions and our core results are reported in column 1 . We employ the DWH approach to test whether the explanatory variables representing the board structure are endogenous. The null hypothesis of DWH test is that the variable in question is exogenous and its rejection implies that compared to an IV approach, the OLS method is inappropriate, i.e., the variable in question is endogenous. The DWH results indicate that the presence of foreigners on the board and foreign ownership are endogenous variables in the model. Likewise, the Hausman test failed to reject the null hypothesis that the individual specific effects or errors are not correlated with the regressors for the ROA model. The study, therefore, employed the RE-2SLS-IV approach to estimate the ROA model by including the control variables based on the full data including all countries.

Hypothesis 1 suggests a positive relationship between board size and firm performance. Column 1 of table 5 reveals that the coefficient of board size is negative and very significant, thus opposing our conjecture. The negative sign implies that a larger board size has an adverse impact 
on the operational performance of the companies listed in the EAC exchanges. Moreover, this observation is in line with the assertion that as board increases in size, its efficiency in terms of discharging the monitoring and advisory roles reduces (Yermack, 1996; Lipton and Lorsch, 1992; Hermalin and Weisbach, 2003). ${ }^{7}$

Hypothesis 2a suggests that presence of foreigners on BoD positively affects firm performance. Table 5 indicates that the coefficient on foreigners on the board is positive and significant, thus supporting this conjecture. It is worth of a note; however, that, most of these foreign directors represent the larger shareholders such as the strategic investors, in the case of privatized SOEs. They, therefore, have every incentive to ensure that the resources that the parent company has invested yields sufficient returns. The findings, nevertheless, are not in line with those of Masulis et al. (2012), who found a negative relationship between ROA and presence of foreign directors on the board.

\section{[Insert Table 5 here]}

The study also investigates the effect of the presence of senior civil servants (or politicians) on the board on ROA. Consistent with our conjecture, in hypothesis $2 b$ and the resource dependence theory, the corresponding coefficient in table 5 is positive and highly significant. This result implies that firms prefer to appoint this type of directors on their boards in order to create linkages with the government, which is an important source of external dependency (Pfeffer, 1972). This is because the government's policies, regulations and enforcements shape the external environment in which businesses operate. In the developing world and in African frontier markets, in particular, this is a major source of risk and uncertainty, because of the weak legal and regulatory framework (La Porta et al., 1997, 1998; Rossouw, 2005; Wanyama et al., 2009, 2013; Claessens and Yurtoglu, 2013). Therefore, creating linkages with the government reduces transaction costs of securing information

\footnotetext{
${ }^{7}$ We also investigated whether the size of the board has a non-linear effect on performance by including the squared term of the board size variable in the model. Both the linear and quadratic terms were statistically insignificant. We, therefore, dropped the latter.
} 
concerning important political decisions, lobbying, risk and uncertainty, and ultimately enhance operating performance. The findings are consistent with prior studies such as those by Hillman (2005) and Lester et al. (2008).

Although significant at the $10 \%$ level only, concerning the effect of education on ROA, our analyses are in line with the prediction of hypothesis $2 \mathrm{c}$. Consistent with the resource dependency theory, the results show that firms with a mix of skills and expertise of directors with higher levels of education perform better than counterparts without. Similar findings are reported by Murphy (2007) and Anderson et al. (2011). The explanation for this observation is that the focus of directors in EAC listed companies is to protect the interests of the shareholders whom they represent. Besides, in most cases, this is the larger shareholders or block-holders that own huge stakes of the issued share capital.

We discussed that foreign ownership can be positively associated with firm performance. The evidence presented in table 5 does not support this expectation. This finding is surprising as it contradicts the main motive of attracting foreign investors by African frontier markets. Among others, given their level of involvement and influence, it was expected that their presence would be reflected in enhancing financial performance.

The result for institutional ownership supports our expectation (at the 10\% statistically significant level) that ownership by institutional-investors is positively associated with ROA. This could mean that institutional investors in EAC exchanges are, to a certain extent, concerned with profitability in contrast to market values of the firms in which they invest. In other words, the existence of institutional ownership may be a signal of good operating performance and higher likelihood of dividend payment (Jensen, 1986; Zeckhauser and Pound, 1990; Short et al., 2002; Grinstein and Michaely, 2005; Amidu and Abor, 2006). The finding is consistent with AlNajjar (2010) who reported that investors in Jordan consider firm profitability as one of the factors when they take their investment decisions. 
The evidence presented in table 5 supports our expectation that ownership by the largest shareholders is positively associated with firm performance. The coefficient for the largest shareholder is positive but marginally significant at the $10 \%$ level. The result suggests that the main shareholders of the EAC firms are concerned with the operational performance.

With respect to the other control variables, table 5 shows that firm size has no significant association with ROA, while sales growth has a positive and significant effect. This means that sales growth determines the operating performance of the firms listed on the EAC exchanges. The finding supports the argument that managers pursue sales growth because it allows them to sustain profitability. Consistent with the agency theory and strategic-alignment hypothesis, the implication of this finding is similar to those of the largest shareholder and institutional ownership. The evidence suggests that main focus of these big investors is on the profitability of the firms. The incentive for managers to pursue sales growth, on the other hand, is to increase their powers by increasing the resources under their control.

Furthermore, the coefficient on leverage has a negative and significant effect on ROA. This suggests that firms with low leverage have higher ROA. This evidence is consistent with the findings by Demsetz and Villalonga (2001) and Cui and Mak (2002) who found a negative effect in the American market. However, the evidence contradicts the long-standing theories such as Modigliani and Miller (1963) with respect to the capital structure irrelevance principle. Finally, we included the exchange dummy variables in the regression model to control for the country specific trends. Table 5 shows that there is no statistical difference in terms of operating performance by firms listed in either of the stock exchanges with reference to the DSE.

\subsection{The impact of the 2008-2009 financial crisis}

In column 2 of table 5, we investigate if our results change when we control for the potential effect of the 2008-2009 financial crisis on the relation between the attributes of board structure (i.e., board size, foreigners on the board, civil servants or politicians on the board, and academic qualifications) and firm performance in EA markets. We also show whether the results for 
ownership structure (i.e., foreign ownership, institutional ownership, and large shareholders) change. The recent financial crisis had a global impact on many countries and several studies have investigated its effect on corporate governance for different countries. For instance, the literature document that the recent financial crisis has a negative relation with board size in Europe (Van Essen et al., 2013) and a U-shaped relation with ownership by large shareholders in China (Lui et al., 2012). To our knowledge, our study is the first to investigate the impact of the 2008-2009 financial crisis on the relation between board structure and firm performance in EA countries.

Following the literature, we create a dummy variable, Crisis, which is 1 for the years 2008 to 2009, and 0 otherwise (e.g., Conyon et al., 2011; Beuselinck et al., 2017), and then interact this binary factor with the variables of board structure to investigate how the relations between these variables and firm performance change during the recent financial crisis period. The statistically insignificant coefficients on the interactions suggest that there is no significant difference between the crisis and non-crisis periods in terms of the effects of the board structure on the corporations' financial performance. More importantly, the coefficients on board structure variables (i.e., board size, foreigners on the board, and civil servants on the board) are still consistent with those in column 1 in table 5, suggesting the robustness of our main findings. The results show that the ownership structure variables are also robust. The reason why our main findings have not changed during the recent financial crisis maybe because of the weak integration of EA countries with the the rest of the international markets, which might mean good diversification opportunities for foreign investors in such remote markets.

\subsection{Analyses for each country}

We conduct analyses for each country as sub-samples to examine whether any individual country's results drive the main results using all countries. The results are reported in table 6 (without considering the effects of the latest global financial crisis) and table 7 (considering the impact of the crisis). It should be noted that the estimation method selected varies across countries depending on the implications of the Hausman and Breusch-Pagan tests (see notes in the regression tables). 
In both tables, board size across six columns is consistently assigned to negative coefficients; yet, the results are not significant in the case of Tanzania. This implies that the negative and significant results in table 5 have been confirmed in Uganda and Kenya. As for the impact of foreigners on the board, the positive and significant finding in column 1 of table 5 appears to be driven by the Kenyan firms only. Moreover, the factor 'civil servants on the board' is significant and positive (i.e., confirming our main results) only in case of Tanzania and Kenya. Finally, the positive impact of education level on financial performance using the full sample can be observed in Tanzania and Uganda. Overall, this section shows that generally our main results are confirmed when the estimations are executed across countries and the results are not driven by a specific country.

\section{[Insert Table 6 here]}

\section{[Insert Table 7 here]}

\section{Conclusion}

This study analyses the association of corporate outcomes with board structure in the East African frontier markets. We find that board size affects firm performance with a negative and significant coefficient estimate; thus, it does not support our hypothesis. This finding, however, supports the school of thought that small boards are effective in monitoring the operating performance.

Our results show that the presence of foreigners on the boards has a strong positive relationship with firm performance, ROA. This result supports our conjecture that foreigners on the board of directors have a positive impact on firm performance. Based on this evidence, the study concludes that the effect of foreign board members in the companies listed in EAC exchanges is observed in the operating performance. The same conclusion is reached with respect to the presence of civil servants on the corporate boards. That is, the finding offers strong support to our hypothesis which states that civil servants (or politicians) on the board have a positive impact on firm performance. In addition, the analyses provide supporting evidence for our hypothesis that directors with MSc and $\mathrm{PhD}$ degrees on the board enhance firm performance. The results lead to the conclusion that 
board members with masters' degree or above have influence on improving a company's performance in the EAC frontier markets.

In addition to above, we document evidence that our results are qualitatively same with and without consideration of the 2008-2009 financial crisis years and that the findings are not driven by a specific country. This provides further support that our main findings are robust.

Overall, the implications of our findings based on the firms from unique environments suggest that the board structures of firms in the frontier markets yield unconventional firm outcomes potentially because of the imperfections stemming from agency conflicts and information asymmetries that take different forms. Our results suggest that, among other aspects, a theoretical model is required that explains how board characteristics in frontier markets perform their roles via various non-conventional channels.

\section{References}

Ackert, L. F. \& Athanassakos, G. (2003), "A simultaneous equations analysis of analysts' forecast bias, analyst following, and institutional ownership." Journal of Business Finance \& Accounting, Vol. 30, No.7-8: pp. 1017-1042.

Ahrens, T., Filatotchev, I., Thomsen, S. (2011), "The research frontier in corporate governance." Journal of Management and Governance. Vol. 15, No.3: pp. 315-325.

Al-Najjar, B. (2010), "Corporate governance and institutional ownership: Evidence from Jordan." Corporate Governance: The International Journal of Business in Society, Vol. 10, No.2: pp. 176-190.

Alves, P., Couto, E. B., Francisci, P. M. (2015), "Board of directors' composition and capital structure." Research in International Business and Finance, Vol. 35, pp. 1-32.

Amidu, M. \& Abor, J. (2006), "Determinants of dividend payout ratios in Ghana." The Journal of Risk Finance, Vol. 7, No.2: pp. 136-145.

Ammann, M., Oesch, D. \& Schmid, M. M. (2011), "Corporate governance and firm value: International evidence." Journal of Empirical Finance, Vol. 18, No.1: pp. 36-55.

Anderson, R. C., Mansi, S. A. \& Reeb, D. M. (2004), "Board characteristics, accounting report integrity, and the cost of debt." Journal of Accounting and Economics, Vol. 37, No.3: pp. 315-342.

Anderson, R. C., Reeb, D. M., Upadhyay, A. \& Zhao, W. (2011), "The economics of director heterogeneity." Financial Management, Vol. 40, No.1: pp. 5-38.

Bai, C.-E., Liu, Q., Lu, J., Song, F. M. \& Zhang, J. (2004), "Corporate governance and market valuation in China." Journal of Comparative Economics, Vol. 32, No.4: pp. 599-616.

Barako, D. G., Hancock, P. \& Izan, H. (2006), "Factors influencing voluntary corporate disclosure by Kenyan companies." Corporate Governance: An International Review, Vol. 14, No.2: pp. 107-125.

Berger, D., Pukthuanthong, K. \& Jimmy Yang, J. (2011), "International diversification with frontier markets." Journal of Financial Economics, Vol. 101, No.1: pp. 227 - 242.

Berglof, E. \& Claessens, S. (2004), Enforcement and corporate governance. Policy Research Working Paper Series 3409. World Bank.

Beuselinck, C., Cao, L., Deloof, M., Xia, X. (2017), "The value of government ownership during the global financial crisis." Journal of Corporate Finance, Vol. 42, pp. 481-493

Bhagat, S. \& Bolton, B. (2008), "Corporate governance and firm performance." Journal of Corporate Finance, Vol. 14, No.257 - 273. 
Black, B. (2001), "The corporate governance behavior and market value of Russian firms." Emerging Markets Review, Vol. 2, No.89 - 108.

Black, B., De Carvalho, A.G., Khanna, V., Kim, W. and Yurtoglu, B., (2017). Corporate governance indices and construct validity. Corporate Governance: An International Review, 25(6), pp.397-410.

Black, B. S., De Carvalho, A. G. \& Gorga, É. (2012), "What matters and for which firms for corporate governance in emerging markets? Evidence from Brazil (and other BRIK countries)." Journal of Corporate Finance, Vol. 18, No.4: pp. 934 - 952.

Bond, S. R. (2002), "Dynamic panel data models: A guide to micro data methods and practice." Portuguese Economic Journal, Vol. 1, No.2: pp. 141-162.

Cheng, S. (2008). 'Board size and the variability of corporate performance', Journal of Financial Economics, 87, pp. 157-176.

Claessens, S. \& Yurtoglu, B. B. (2013), "Corporate governance in emerging markets: A survey." Emerging Markets Review, Vol. 15, No.1-33.

Coles, J. L., Daniel, N. D. \& Naveen, L. (2008), "Does one size fit all?" Journal of Financial Economics, Vol. 87 No.2 pp. 329 - 356.

Conyon, M., Judge, W. Q., \& Useem, M. (2011). Corporate governance and the 2008-09 financial crisis. Corporate Governance: An International Review, Vol. 19, No. 5: pp. 399-404.

Cronqvist, H. \& Nilsson, M. (2003), "Agency costs of controlling minority shareholders." Journal of Financial and Quantitative Analysis, Vol. 38, No.04: pp. 695-719.

Cui, H. \& Mak, Y. T. (2002), "The relationship between managerial ownership and firm performance in high R\&D firms." Journal of Corporate Finance, Vol. 8, No.4: pp. 313-336.

Cuomo, F., Mallin, C., Zattoni, A. (2016), " Corporate Governance Codes: A Review and Research Agenda." Corporate Governance: An International Review, Vol. 24, No. 3: pp. 222-241

Dahlquist, M., Pinkowitz, L., Stulz, R. M. \& Williamson, R. (2003), "Corporate governance and the home bias." Journal of Financial and Quantitative Analysis, Vol. 38, No.1: pp. 87-110.

Daily, C. M., Dalton, D. R. \& Cannella, A. A. (2003), "Corporate governance: Decades of dialogue and data." Academy of Management Review, Vol. 28, No.3: pp. 371-382.

Dalton, D. R., Daily, C. M., Johnson, J. L. \& Ellstrand, A. E. (1999), "Number of directors and financial performance: A meta-analysis." Academy of Management Journal, Vol. 42, No.6: pp. 674-686.

Demsetz, H. \& Lehn, K. (1985), "The structure of corporate ownership: Causes and consequences." Journal of Political Economy, Vol. 93, No.6: pp. 1155 -1177.

Demsetz, H. \& Villalonga, B. (2001), "Ownership structure and corporate performance." Journal of Corporate Finance, Vol. 7, No.3: pp. 209-233.

Denis, D. K. \& McConnell, J. J. (2003), "International corporate governance." Journal of Financial and Quantitative Analysis, Vol. 38, No.1: pp. 1-36.

Dmitry, G., Iyabo Masha \& Dunn, D. (2008), Progress toward harmonization of capital account regulations and capital market integration in the East African community. IMF Country Report No. 09/37, UGANDA : Selected Issues. Washington, D.C., International Monetary Fund

Ehikioya, B. I. (2009), "Corporate governance structure and firm performance in developing economies: Evidence from Nigeria." Corporate Governance, Vol. 9, No.3: pp. 231-243.

Faccio, M. \& Lasfer, M. A. (2000), "Do occupational pension funds monitor companies in which they hold large stakes?" Journal of Corporate Finance, Vol. 6, No.1: pp. 71-110.

Fairchild, R., Guney, Y. \& Thanatawee, Y. (2014), "Corporate dividend policy in Thailand: Theory and evidence." International Review of Financial Analysis, Vol. 31, No.129-151.

Fama, E. F. \& Jensen, M. C. (1983), "Separation of ownership and control." Journal of Law and Economics., Vol. 26, No.301.

FTSE (2014), Frontier markets: Accessing the next frontier. In FTSE International Limited (Ed.) London.

Gakeri, J. K. (2013), "Enhancing Kenya's securities markets through corporate governance: Challenges and opportunities." International Journal of Humanities and Social Science, Vol. 3, No.6: pp. 94 - 117.

Gibson, S. M. (2003), "Is corporate governance ineffective in emerging markets? ." The Journal of Financial and Quantitative Analysis, Vol. 38, No.1: pp. 231-250.

Gillan, S. \& Starks, L. (2005), "Corporate governance, corporate ownership, and the role of institutional investors: A global perspective." Journal of Applied Finance, Vol. 13, No.2: pp. Fall/Winter

Girard, E. \& Sinha, A. (2008), "Risk and return in the next frontier." Journal of Emerging Market Finance, Vol. 7, No.1: pp. 43-80.

Grinstein, Y. \& Michaely, R. (2005), "Institutional holdings and payout policy." The Journal of Finance, Vol. 60, No.3: pp. 1389-1426. 
Gulamhussen, M. A. \& Guerreiro, L. (2009), "The influence of foreign equity and board membership on corporate strategy and internal cost management in Portuguese banks." Management Accounting Research, Vol. 20, No.1: pp. 6-17.

Guo, C. (2019), "The impact of the anti-corruption campaign on the relationship between political connections and preferential bank loans: the case of China." Emerging Markets Finance and Trade, Vol. 55, No.3: pp. 671-686

Hackman, J. R. and C. G. Morris (1975). 'Group tasks, group interaction process, and group performance effectiveness: a review and proposed integration'. In L. Berkowitz (ed.), Advances in Experimental Social Psychology, Vol. 8. New York: Academic Press.

Hai, J., Min, H., \& Barth, J. R. (2018). "On foreign shareholdings and agency costs: new evidence from China." Emerging Markets Finance and Trade, Vol. 54, No.12: pp.2815-2833.

Hair, J. F., Black, W. C., Babin, B. J., Anderson, R. E. \& Tatham, R. L. (2006), "Multivariate data analysis," (6th edn.),New Jersey, Pearson Prentice Hall.

Hermalin, B. E. \& Weisbach, M. S. (2003), "Boards of directors as an endogenously determined institution: A survey of the economic literature." Economic Policy Review, Vol. 9, No.7 - 29.

Hillman, A. J. (2005), "Politicians on the board of directors: Do connections affect the bottom line?" Journal of Management, Vol. 31, No.3: pp. 464-481.

Hillman, A. J. \& Dalziel, T. (2003), "Boards of directors and firm performance: Integrating agency and resource dependence perspectives." The Academy of Management Review, No.383-396.

Holderness, C. G. \& Sheehan, D. P. (1988), "The role of majority shareholders in publicly held corporations: An exploratory analysis." Journal of Financial Economics, Vol. 20, No.317-346.

IMF (2011), Regional economic outlook. Sub-Saharan Africa: Capital inflows to frontier markets in SubSaharan Africa. World Economic and Financial Surveys, 0258-7440. Washington, D.C., International Monetary Fund.

Jensen, M. C. (1986), "Agency cost of free cash flow, corporate finance, and takeovers." Corporate Finance, and Takeovers. American Economic Review, Vol. 76, No.2: pp.

Jensen, M. C. (1993), "The modern industrial revolution, exit, and the failure of internal control systems." The Journal of Finance, Vol. 48, No.3: pp. 831-880.

Judge, W., Li, S., Pinsker, R. (2010). "National Adoption of International Accounting Standards: An Institutional Perspective." Corporate Governance: An International Review, Vol. 18, No.3: pp. 161174.

Kaduma, I. M. (2002), "Corporate governance and the need for national codes." ECSAFA/NBAA seminar on corporate govnernance and development of appropriate national corporate codes. Dar es Salaam, National Board of Accountants and Auditors (NBAA).

Kaufmann, D., Kraay, A. \& Mastruzzi, M. (2011), "The worldwide governance indicators: Methodology and analytical issues." Hague Journal on the Rule of Law, Vol. 3, No.2: pp. 220-246.

Khanna, T. \& Palepu, K. (2000), "Is group affiliation profitable in emerging markets? An analysis of diversified Indian business groups." Journal of Finance, Vol. 55 No. 2: pp. 867- 891.

Kibola, H. S. (2002), The legal and administrative framework of corporate governance in Tanzania. ECSAFA/NBAA seminar on corporate governance and development of appropriate national corporate codes. Dar es Salaam, National Board of Accountants and Auditors (NBAA).

Klapper, L. F. \& Love, I. (2004), "Corporate governance, investor protection, and performance in emerging markets." Journal of Corporate Finance, Vol. 10, No.5: pp. 703-728.

Klein, A. (1998), "Firm performance and board committee structures." Journal of Law and Economics, Vol. 41, No.1: pp. $275-303$.

Klein, A. (2002), "Economic determinants of audit committee independence." Accounting Review Vol. 77, No.2: pp. 435 - 452.

Kumar, P., \& Zattoni, A. (2017). Board monitoring and effectiveness: Antecedents and implications. Corporate Governance: An International Review, Vol 25, No. 2: pp. 76-77.

Kumar, P., \& Zattoni, A. (2014). Large shareholders and corporate governance outside the United States and United Kingdom. Corporate Governance: An International Review, Vol. 22, No. 4: pp. 294-295.

Kumar, P., \& Ramchand, L. (2008). Takeovers, market monitoring, and international corporate governance. RAND Journal of Economics, Vol 39, No. 3: pp. 850-874.

La Porta, R., Lopez-de-Silanes, F., Shleifer, A. \& Vishny, R. (2000), "Investor protection and corporate governance " Journal of Financial Economics, Vol. 58, No.3-27.

La Porta, R., Lopez-de-Silanes, F., Shleifer, A. \& Vishny, R. W. (1997), "Legal determinants of external finance." Journal of Finance, Vol. 52, No.3: pp. 1131-1150. 
La Porta, R., Lopez-de-Silanes, F., Shleifer, A. \& Vishny, R. W. (1998), "Law and finance." Journal of Political Economy Vol. 106, No.6: pp. 1113 -1155.

La Porta, R., López de Silanes, F. \& Shleifer, A. (1999), "Corporate ownership around the world." Journal of Finance, Vol. 54, No.2: pp. 471-517.

Larcker, D. F., So, E. C., \& Wang, C. C. (2013), "Boardroom centrality and firm performance." Journal of Accounting and Economics, Vol. 55, No. 2-3: pp. 225-250.

Lester, R. H., Hillman, A., Zardkoohi, A. \& Cannella, A. A. (2008), "Former government officials as outside directors: The role of human and social capital." Academy of Management Journal, Vol. 51, No.5: pp. 999-1013.

Lindemanis, M., Loze, A., \& Pajuste, A. (2019). "The effect of domestic to foreign ownership change on firm performance in Europe." International Review of Financial Analysis, forthcoming.

Lipton, L. \& Lorsch, J. (1992), "A modest proposal for improved corporate governance." The Business Lawyer, Vol. 48, No.59- 77.

Liu, C., Uchida, K., Yang., Y. (2012), "Corporate governance and firm value during the global financial crisis: Evidence from China." International Review of Financial Analysis, Vol. 21, pp 70-80.

Liu, J., Hu, M., Zhang, H., Carrick, J. (2019), "Corruption and entrepreneurship in emerging markets." Emerging Markets Finance and Trade, Vol. 55, No. 5: pp.1051-1068.

Love, I. (2011), "Corporate governance and performance around the world: What we know and what we don't." The World Bank Research Observer, Vol. 26, No.1: pp. 42 - 70.

Mak, Y. T. \& Li, Y. (2001), "Determinants of corporate ownership and board structure: Evidence from Singapore." Journal of Corporate Finance, Vol. 7, No.3: pp. 235-256.

Masulis, R. W., Wang, C. \& Xie, F. (2012), "Globalizing the boardroom: The effects of foreign directors on corporate governance and firm performance." Journal of Accounting and Economics, Vol. 53, No.3: pp. 527-554.

Mertzanis, C., Basuony, M. A. K., Mohamed, E. K. A., (2019), "Social institutions, corporate governance and firm-performance in the MENA region." Research in International Business and Finance, Vol. 48, pp. 75-96.

McConnell, J. J. \& Servaes, H. (1990), "Additional evidence on equity ownership and corporate value." Journal of Financial Economics, Vol. 27, No.2: pp. 595-612.

Mínguez-Vera, A. \& Martín-Ugedo, J. F. (2007), "Does ownership structure affect value? A panel data analysis for the Spanish market." International Review of Financial Analysis, Vol. 16, No.1: pp. 8198.

Modigliani, F. \& Miller, M. H. (1963), "Corporate income taxes and the cost of capital: A correction." The American Economic Review, Vol. 53, No.3: pp. 433-443.

Morey, M., Gottesman, A., Baker, E. \& Godridge, B. (2009), "Does better corporate governance result in higher valuations in emerging markets? Another examination using a new data set." Journal of Banking \& Finance, Vol. 33, No.2: pp. 254-262.

Murphy, P. J. (2007), "Do business school professors make good executive managers?" The Academy of Management Perspectives, Vol. 21, No.3: pp. 29-50.

Musikali, L. M. (2008), "The law affecting corporate governance in Kenya: A need for review." International Company and Commercial Law Review, Vol. 19, No.7: pp. 213-227.

Muth, M. \& Donaldson, L. (2002), "Stewardship theory and board structure: A contingency approach." Corporate Governance: An International Review, Vol. 6, No.1: pp. 5-28.

Nellor, D. C. L. (2008), "The rise of Africa's "frontier" markets." Finance \& Development, Vol. 45, No.3: pp. 30-33.

Nicholson, G. J. \& Kiel, G. C. (2007), "Can Directors Impact Performance? A case-based test of three theories of corporate governance." Corporate Governance: An International Review, Vol. 15, No.4: pp. 585-608.

Okpara, J. O. (2011), "Corporate governance in a developing economy: Barriers, issues, and implications for firms." Corporate Governance, Vol. 11, No.2: pp. 184-199.

Oxelheim, L. \& Randøy, T. (2003), "The impact of foreign board membership on firm value." Journal of Banking \& Finance, Vol. 27, No.12: pp. 2369-2392.

Outa, E.R. and Waweru, N.M., (2016). "Corporate governance guidelines compliance and firm financial performance: Kenya listed companies". Managerial Auditing Journal, 31(8/9), pp.891-914.

Ozkan, N. (2007), "Do corporate governance mechanisms influence CEO compensation? An empirical investigation of UK companies." Journal of Multinational Financial Management, Vol. 17, No.5: pp. 349-364. 
Pelted, L. H., Eisenhardt, K. M. \& Xin, K. R. (1999), "Exploring the black box: An analysis of work diversity, conflict, and performance." Administrative Science Journal, Vol. 44, No.128 -138.

Peng, M. W. (2004), "Outside directors and firm performance during institutional transitions." Strategic Management Journal Vol. 25, No.453 - 471.

Pfeffer, J. (1972), "Size and composition of corporate boards of directors: The organization and its environment." Administrative Science Quarterly, No.218-228.

Pfeffer, J. (1973), "Size, composition, and function of hospital boards of directors: A study of organizationenvironment linkage." Administrative Science Quarterly, No.349-364.

Pillai, R., Al-Malkawi, N. (2018), "On the relationship between corporate governance and firm performance: Evidence from GCC countries", Research in International Business and Finance, Vol. 44, pp. 394410.

Rose, C. (2007), "Does female board representation influence firm performance? The Danish evidence." Corporate Governance: An International Review, Vol. 15, No.2: pp. 404-413.

Rossouw, G. (2005), "Business ethics and corporate governance in Africa." Business \& Society, Vol. 44, No.1: pp. 94-106.

Sarkar, J. \& Sarkar, S. (2000), "Large shareholder activism in corporate governance in developing countries: Evidence from India." International Review of Finance, Vol. 1, No.3: pp. 161- 194.

Shleifer, A. \& Vishny, R. W. (1997), "A survey of corporate governance." The Journal of Finance, Vol. 52, No.2: pp. 737 - 783.

Short, H., Zhang, H. \& Keasey, K. (2002), "The link between dividend policy and institutional ownership." Journal of Corporate Finance, Vol. 8, No.2: pp. 105-122.

Smith, M. P. (1996), "Shareholder activism by institutional investors: Evidence from CalPERS." The Journal of Finance, Vol. 51, No.1: pp. 227-252.

Stock, J. H., Wright, J. H. \& Yogo, M. (2002), "A survey of weak instruments and weak identification in generalized method of moments." Journal of Business and Economic Statistics, Vol. 20, No.4: pp. $518-529$.

Tam, O. K. \& Tan, M. G.-S. (2007), "Ownership, governance and firm performance in Malaysia." Corporate Governance: An International Review, Vol. 15, No.2: pp. 208-222.

The Committee (2001), Manual on corporate governance in Tanzania. IN Steering Committee on Corporate Governance in Tanzania (Ed.) Dar es Salaam.

Tao, Q., Liu, M., Feng, Q., \& Zhu, Y. (2018), "How do institutional investors affect corporate performance? Evidence from private placements in China." Emerging Markets Finance and Trade, Vol. 54, No.15: pp. 3454-3469.

Tong, S. \& Ning, Y. (2004), "Does capital structure affect institutional investor choices?" The Journal of Investing, Vol. 13, No.4: pp. 53-66.

Van Essen, M., Peter-Jan, E., Carney, M. (2013), "Does "Good" Corporate Governance Help in a Crisis? The Impact of Country- and Firm-Level Governance Mechanisms in the European Financial Crisis." Corporate Governance: An International Review, Vol. 21, No. 3 pp. 201-224.

Wanyama, S., Burton, B. \& Helliar, C. (2009), "Frameworks underpinning corporate governance: Evidence on Ugandan perceptions " Corporate Governance: An International Review, Vol. 17, No.2: pp. 159175 .

Wanyama, S., Burton, B. \& Helliar, C. (2013), "Stakeholders, accountability and the theory-practice gap in developing nations' corporate governance systems: Evidence from Uganda." Corporate Governance: The International Journal of Business in Society, Vol. 13, No.1: pp. 18-38.

Watson, W. E., Kumar, K. \& Michealson, L. K. (1993), "Cultural diversity's impact on interaction and performance: Comparing homogeneous and diverse task groups." Academy of Management Journal, Vol. 36, No.3: pp. 590-602.

Waweru, N. M. (2014), "Determinants of quality corporate governance in Sub-Saharan Africa: Evidence from Kenya and South Africa." Managerial Auditing Journal, Vol. 29, No.5: pp. 455-485.

WEF (2012), The Global Competitiveness Report 2012-2013: Full Data Edition. IN Schwab, K. (Ed.) Insight Report. Geneva, World Economic Forum.

WEF (2013), The Global Competitiveness Report 2013-2014: Full Data Edition. IN Schwab, K. (Ed.) Insight Report. Geneva, World Economic Forum.

Welch., I. (2004), "Capital Strcuture and Stock Returns." Journal of Political Economy, Vol. 112, No. 1: pp. 106-132.

Wintoki, M. B., Linck, J. S. \& Netter, J. M. (2012), "Endogeneity and the dynamics of internal corporate governance." Journal of Financial Economics, Vol. 105, No.3: pp. 581-606. 
Wooldridge, M. J. (2009), "Introductory econometrics: A modern approach," (4th edn.), South-Western CENGAGE Learning.

Yamahaki, C., Frynas, J. G. (2016), " Institutional Determinants of Private Shareholder Engagement in Brazil and South Africa: The Role of Regulation", Corporate Governance: An International Review, Vol. 25, No.5: pp. 509-527.

Yermack, D. (1996), "Higher market valuation of companies with a small board of directors." Journal of Financial Economics, Vol. 40, No.2: pp. 185-211.

Young, M. N., Peng, M. W., Ahlstrom, D., Bruton, G. D. \& Jiang, Y. (2008), "Corporate governance in emerging economies: A review of the principal-principal perspective." Journal of Management Studies, Vol. 45, No.1: pp. 196-220.

Zona, F., \& Zattoni, A. (2007), "Beyond the black box of demography: Board processes and task effectiveness within Italian firms." Corporate Governance: An International Review, Vol. 23, No.15, 158-159.

Zona, F., \& Zattoni, A. (2013), " A Contingency Model of Boards of Directors and Firm Innovation: The Moderating Role of Firm Size." Corporate Governance: An International Review, Vol. 24, No.15, 299-315.

Zeckhauser, R. J. \& Pound, J. (1990), "Are large shareholders effective monitors? An investigation of share ownership and corporate performance." Asymmetric information, corporate finance, and investment. University of Chicago Press: pp. 149-180. 


\section{Appendix}

Table A1: Variable definitions and measurements

\begin{tabular}{|c|c|c|c|}
\hline & Measure & Sign & Source \\
\hline \multicolumn{4}{|l|}{ Dependent variables } \\
\hline$\overline{\text { Return on assets (ROA) }}$ & $\begin{array}{l}\text { The proportion of profit before interest and tax } \\
\text { (EBIT) over total assets. }\end{array}$ & & Klapper and Love, 2004; Ehikioya, 2009 \\
\hline \multicolumn{4}{|l|}{ Independent variables } \\
\hline \multicolumn{4}{|l|}{ Board structure variables } \\
\hline Board size (bsize) & Natural log of the total number of board members & + & $\begin{array}{l}\text { Yermack, } 1996 \text {; Coles et al., } 2008 \text {; Ehikioya, } \\
2009\end{array}$ \\
\hline $\begin{array}{l}\text { Foreigners on the board } \\
\text { (bfgn) }\end{array}$ & $\begin{array}{l}\text { Proportion of foreigners to the total number of } \\
\text { board members }\end{array}$ & + & Oxelheim and Randoy, 2003 \\
\hline $\begin{array}{l}\text { Senior civil servants or } \\
\text { politicians (civ) }\end{array}$ & $\begin{array}{l}\text { Proportion of senior civil servants (or politicians) } \\
\text { to total number of board members }\end{array}$ & + & $\begin{array}{l}\text { Muth and Donaldson, 2002; Peng, 2004; } \\
\text { Hillman, 2005; Rossouw, 2005; Lester et al., } \\
\text { 2008; Wanyama et al., } 2009\end{array}$ \\
\hline $\begin{array}{l}\text { Academic Qualification } \\
\text { (ed) }\end{array}$ & $\begin{array}{l}\text { Proportion of directors with masters' degree and } \\
\text { directors with } \mathrm{PhD} \text { to total number of board } \\
\text { members }\end{array}$ & + & $\begin{array}{l}\text { Anderson et al., 2004; Murphy; 2007; Rose, } \\
\text { 2007; Ehikioya, 2009; Anderson et al., } 2011\end{array}$ \\
\hline \multicolumn{4}{|l|}{ Control variables } \\
\hline \multicolumn{4}{|l|}{$\begin{array}{l}\text { Ownership structure } \\
\text { controls }\end{array}$} \\
\hline Largest shareholder (big) & $\begin{array}{l}\text { Proportion of shares held by the biggest } \\
\text { shareholder }\end{array}$ & + & $\begin{array}{l}\text { Holderness and Sheehan, 1988; McConnell and } \\
\text { Servaes, 1990; Khanna and Palepu, 2000; } \\
\text { Sarkar and Sarkar, 2000; Bai et al., 2004; } \\
\text { Minguez-Vera and Martin-Ugedo, 2007; Tam } \\
\text { and Tan, 2007; Oxelheim and Randøy, } 2003\end{array}$ \\
\hline Foreign ownership (fown) & Proportion of shares held by foreign investors & + & $\begin{array}{l}\text { Dahlquist, et al.,2003; Bai et al., 2004; Peng, } \\
\text { 2004; Young et al., } 2008\end{array}$ \\
\hline $\begin{array}{l}\text { Institutional ownership } \\
\text { (inst) }\end{array}$ & Proportion of shares held by institutional investors & + & $\begin{array}{l}\text { McConnell and Servaes, 1990; Mak and Li, } \\
\text { 2001; Dahlquist, et a., 2003; Tong and Ning, } \\
2004\end{array}$ \\
\hline \multicolumn{4}{|l|}{ Other control variables } \\
\hline Firm size (fsize) & Logarithm of total assets adjusted for inflation & + & Klapper and Love, 2004; Ehikioya, 2009 \\
\hline Sales growth (sgr) & $\begin{array}{l}\text { We measure sales growth rate as the percentage } \\
\text { growth in total sales }\end{array}$ & & Klapper and Love, 2004 \\
\hline Leverage (lev) & $\begin{array}{l}\text { Debt-ratio is calculated as total debt divided by } \\
\text { book value of total assets }\end{array}$ & - & Tong and Ning, 2004; Ehikioya, 2009 \\
\hline Industry sector (dsec) & $\begin{array}{l}\text { We include six sector dummy variables to control } \\
\text { for the effects of industry-specific factors as } \\
\text { categorized by the NSE }\end{array}$ & & Ehikioya, 2009 \\
\hline Year (yr) & $\begin{array}{l}\text { We include year dummy variables to control for } \\
\text { time fixed effects }\end{array}$ & & \\
\hline Stock exchange (dexch) & $\begin{array}{l}\text { We include three stock exchange dummy variables } \\
\text { to control for the country specific effects }\end{array}$ & & \\
\hline
\end{tabular}


Table 1: Rankings on the global competitiveness index in the survey of 144 countries

\begin{tabular}{|c|c|c|c|c|c|c|c|c|c|c|c|c|c|c|}
\hline \multirow[b]{2}{*}{ Country } & \multicolumn{6}{|c|}{ 2012-13 } & \multirow[b]{2}{*}{ GCI } & \multicolumn{6}{|c|}{ 2013-14 } & \multirow[b]{2}{*}{ GCI } \\
\hline & PR & EBF & SARS & ECB & PMSI & SIP & & PR & EBF & SARS & ECB & PMSI & SIP & \\
\hline USA & 42 & 29 & 37 & 23 & 33 & 5 & 7 & 33 & 32 & 36 & 15 & 27 & 6 & 5 \\
\hline UK & 5 & 12 & 13 & 15 & 16 & 10 & 8 & 4 & 12 & 16 & 21 & 15 & 10 & 10 \\
\hline South Africa & 26 & 48 & 1 & 1 & 2 & 10 & 52 & 20 & 37 & 1 & 1 & 1 & 10 & 53 \\
\hline Botswana & 46 & 37 & 50 & 42 & 44 & 39 & 79 & 41 & 39 & 48 & 50 & 50 & 41 & 74 \\
\hline Kenya & 110 & 102 & 81 & 79 & 87 & 80 & 106 & 86 & 78 & 86 & 74 & 82 & 84 & 96 \\
\hline Tanzania & 106 & 109 & 114 & 78 & 94 & 80 & 120 & 97 & 122 & 127 & 102 & 110 & 84 & 125 \\
\hline Uganda & 80 & 89 & 105 & 48 & 97 & 110 & 123 & 107 & 98 & 118 & 67 & 117 & 116 & 129 \\
\hline
\end{tabular}

Source: World Economic Forum: The Global Competitiveness Report

Note: $\mathrm{PR}=$ Property rights; EBF = Ethical behaviour of firms; SARS = Strength of auditing and reporting standards; ECB = Efficacy of corporate boards; PMSI = Protection of minority shareholders' interests; SIP = Strength of investor protection, $1-10($ Best $)$; and GCI = Global Competitiveness Index 
Table 2: Summary of firm-year observations

\begin{tabular}{|c|c|c|c|c|c|c|c|c|c|c|c|c|c|c|c|}
\hline & 2000 & 2001 & 2002 & 2003 & 2004 & 2005 & 2006 & 2007 & 2008 & 2009 & 2010 & 2011 & 2012 & 2013 & Total \\
\hline \multicolumn{16}{|c|}{ Panel A: Observations by stock exchange } \\
\hline DSE (Tanzania) & 4 & 4 & 5 & 6 & 6 & 6 & 7 & 7 & 7 & 7 & 8 & 8 & 9 & 9 & 93 \\
\hline NSE (Kenya) & 4 & 4 & 7 & 24 & 27 & 27 & 31 & 33 & 34 & 34 & 33 & 33 & 32 & 29 & 352 \\
\hline USE (Uganda) & 0 & 2 & 2 & 2 & 2 & 3 & 3 & 3 & 3 & 3 & 3 & 3 & 4 & 4 & 37 \\
\hline Total & 8 & 10 & 14 & 32 & 35 & 36 & 41 & 43 & 44 & 44 & 44 & 44 & 45 & 42 & 482 \\
\hline \multicolumn{16}{|c|}{ Panel B: Observations by industry categorization } \\
\hline Agriculture & 0 & 0 & 0 & 5 & 5 & 5 & 5 & 6 & 6 & 6 & 6 & 6 & 5 & 3 & 58 \\
\hline $\begin{array}{l}\text { Automobiles \& } \\
\text { Accessories }\end{array}$ & 0 & 0 & 0 & 2 & 3 & 3 & 3 & 3 & 3 & 3 & 3 & 3 & 3 & 3 & 32 \\
\hline $\begin{array}{l}\text { Commercial \& } \\
\text { Services }\end{array}$ & 1 & 1 & 3 & 6 & 6 & 7 & 9 & 9 & 9 & 9 & 9 & 9 & 10 & 10 & 98 \\
\hline $\begin{array}{l}\text { Construction \& } \\
\text { Allied }\end{array}$ & 2 & 3 & 4 & 6 & 7 & 7 & 8 & 8 & 8 & 8 & 9 & 9 & 9 & 9 & 97 \\
\hline $\begin{array}{l}\text { Energy \& } \\
\text { Petroleum }\end{array}$ & 1 & 1 & 2 & 4 & 4 & 4 & 5 & 5 & 5 & 5 & 5 & 5 & 6 & 6 & 58 \\
\hline $\begin{array}{l}\text { Manufacturing \& } \\
\text { Allied }\end{array}$ & 4 & 5 & 5 & 9 & 10 & 10 & 11 & 11 & 11 & 11 & 10 & 10 & 10 & 10 & 127 \\
\hline $\begin{array}{l}\text { Telecommunicati } \\
\text { on \&Technology }\end{array}$ & 0 & 0 & 0 & 0 & 0 & 0 & 0 & 1 & 2 & 2 & 2 & 2 & 2 & 1 & 12 \\
\hline Total & 8 & 10 & 14 & 32 & 35 & 36 & 41 & 43 & 44 & 44 & 44 & 44 & 45 & 42 & 482 \\
\hline
\end{tabular}


Table 3: Descriptive statistics - full sample

\begin{tabular}{|c|c|c|c|c|c|c|c|c|c|c|}
\hline & $\mathbf{N}$ & Mean & SD & Min & 25th & 50th & 75th & Max & Skew. & Kurtosis \\
\hline \multicolumn{11}{|l|}{ Dependent variable } \\
\hline Return on assets (ROA) & 482 & 0.12 & 0.11 & -0.04 & 0.04 & 0.09 & 0.18 & 0.38 & 0.89 & 3.10 \\
\hline \multicolumn{11}{|l|}{ Board structure variables (independent variables) } \\
\hline Board size (bsize) & 482 & 10.36 & 3.37 & 3.00 & 8.00 & 10.00 & 13.00 & 22.00 & 0.39 & 2.79 \\
\hline Proportion of foreigners on the board (bfgn) & 482 & 0.28 & 0.22 & 0.00 & 0.10 & 0.27 & 0.44 & 1.00 & 0.38 & 2.36 \\
\hline Proportion of civil servants on the board (civ) & 482 & 0.12 & 0.14 & 0.00 & 0.00 & 0.09 & 0.20 & 0.50 & 1.20 & 3.73 \\
\hline Proportion of members with masters or higher (ed) & 482 & 0.35 & 0.24 & 0.00 & 0.17 & 0.33 & 0.50 & 1.00 & 0.48 & 2.60 \\
\hline \multicolumn{11}{|l|}{ Control variables for ownership structure } \\
\hline$\overline{\text { Largest shareholder (big) }}$ & 482 & 0.50 & 0.17 & 0.12 & 0.36 & 0.51 & 0.63 & 0.77 & -0.32 & 2.32 \\
\hline Foreign ownership (fown) & 482 & 0.30 & 0.29 & 0.00 & 0.04 & 0.17 & 0.60 & 0.94 & 0.61 & 1.87 \\
\hline Institutional ownership (inst) & 482 & 0.51 & 0.32 & 0.00 & 0.18 & 0.63 & 0.78 & 0.97 & -0.42 & 1.64 \\
\hline \multicolumn{11}{|l|}{ Other controls } \\
\hline$\overline{\text { Firm size (fsize) }}$ & 482 & 2.68 & 2.21 & -2.96 & 1.83 & 2.95 & 4.17 & 6.73 & -0.67 & 2.98 \\
\hline Sales growth (sgr) & 482 & 0.10 & 0.16 & -0.22 & 0.01 & 0.11 & 0.19 & 0.47 & 0.13 & 3.10 \\
\hline Leverage (lev) & 482 & 0.16 & 0.17 & 0.00 & 0.00 & 0.11 & 0.30 & 0.54 & 0.76 & 2.31 \\
\hline
\end{tabular}

Notes: This table provides summary statistics for the data employed throughout the analysis. Data for board characteristics and ownership were collected manually from the published annual reports of the respective companies. Table A1 in the Appendix provides the definitions of the variables. 
Table 4: Pairwise correlation matrix

\begin{tabular}{|c|c|c|c|c|c|c|c|c|c|c|}
\hline & ROA & big & fown & inst & bsize & bfgn & civ & ed & fsize & sgr \\
\hline ROA & 1.000 & & & & & & & & & \\
\hline big & $0.270^{*}$ & 1.000 & & & & & & & & \\
\hline fown & $0.253 *$ & -0.079 & 1.000 & & & & & & & \\
\hline inst & $0.319 *$ & $0.246^{*}$ & $0.215^{*}$ & 1.000 & & & & & & \\
\hline bsize & $-0.158 *$ & -0.027 & 0.034 & -0.050 & 1.000 & & & & & \\
\hline bfgn & $0.266^{*}$ & $0.230 *$ & $0.204^{*}$ & $0.236^{*}$ & $-0.109 *$ & 1.000 & & & & \\
\hline civ & $0.132 *$ & -0.082 & 0.073 & -0.013 & $0.390 *$ & $-0.181 *$ & 1.000 & & & \\
\hline ed & $0.296^{*}$ & $0.241 *$ & -0.004 & $0.218^{*}$ & $0.175^{*}$ & 0.054 & $0.257^{*}$ & 1.000 & & \\
\hline fsize & $-0.393 *$ & -0.071 & $-0.140 *$ & $-0.250 *$ & $0.440 *$ & $-0.243 *$ & 0.042 & $-0.246^{*}$ & 1.000 & \\
\hline sgr & $0.148 *$ & -0.086 & -0.053 & 0.029 & -0.011 & 0.068 & -0.044 & -0.037 & 0.042 & 1.000 \\
\hline lev & $-0.394 *$ & $-0.286^{*}$ & -0.089 & $-0.187 *$ & $0.225^{*}$ & -0.055 & $0.158 *$ & -0.027 & 0.042 & -0.012 \\
\hline
\end{tabular}

Notes: This table presents the pairwise correlation matrix for the data employed in the analysis. Data for board characteristics and ownership were collated manually from the published annual reports of the respective companies. Variables' definitions and measurements are presented in table A1 in the Appendix. $* \mathrm{p}<0.05$ 
Table 5: The relationship between board structure and firm performance: all countries

\begin{tabular}{|c|c|c|}
\hline & Without crisis interactions & With crisis interactions \\
\hline Board size & $-0.070^{* * *}(0.018)$ & $-0.063^{* * *}(0.019)$ \\
\hline Foreigners on the board & $0.166^{* * *}(0.048)$ & $0.131^{* * *}(0.037)$ \\
\hline Civil servants on the board & $0.238^{* * *}(0.057)$ & $0.200^{* * *}(0.052)$ \\
\hline Education & $0.054^{*}(0.028)$ & $0.048^{*}(0.027)$ \\
\hline Largest shareholder & $0.052^{*}(0.029)$ & $0.066^{*}(0.035)$ \\
\hline Foreign ownership & $0.015(0.033)$ & $0.014(0.026)$ \\
\hline Institutional ownership & $0.033^{*}(0.018)$ & $0.041^{* *}(0.017)$ \\
\hline Firm size & $-0.008(0.007)$ & $-0.006(0.006)$ \\
\hline Sales growth & $0.109^{* * *}(0.021)$ & $0.107^{* * *}(0.021)$ \\
\hline Leverage & $-0.144^{* * *}(0.030)$ & $-0.149^{* * *}(0.029)$ \\
\hline Crisis*Board size & & $-0.025(0.024)$ \\
\hline Crisis* Foreigners on the board & & $-0.021(0.044)$ \\
\hline Crisis* Civil servants on the board & & $0.011(0.067)$ \\
\hline Crisis* Education & & $0.045(0.039)$ \\
\hline Crisis* Largest shareholder & & $-0.000(0.067)$ \\
\hline Crisis* Foreign ownership & & $0.021(0.034)$ \\
\hline Crisis* Institutional ownership & & $-0.043(0.028)$ \\
\hline Crisis dummy & & $0.077(0.069)$ \\
\hline Constant & $0.115(0.075)$ & $0.121^{*}(0.069)$ \\
\hline \multicolumn{3}{|l|}{ Exchange dummies } \\
\hline Uganda Securities Exchange & $0.015(0.052)$ & $-0.005(0.044)$ \\
\hline Nairobi Securities Exchange & $0.022(0.049)$ & $-0.003(0.041)$ \\
\hline Observations & 482 & 482 \\
\hline Number of firms & 47 & 47 \\
\hline $\mathrm{R}^{2}$ & 0.483 & 0.5237 \\
\hline F-test & $6.17^{* * *}$ & $5.84^{* * *}$ \\
\hline Breusch-Pagan LM test $\chi^{2}$ & $235.29^{* * *}$ & $237.95^{* * *}$ \\
\hline Hausman test $\chi^{2}$ & 16.45 & 22.18 \\
\hline Durbin-Wu-Hausman F-test & $4.10^{* *}$ & $4.04^{* *}$ \\
\hline First stage F-test & $2577.71^{* * *}$ & $2645.49^{* * *}$ \\
\hline Method & RE-2SLS-IV & RE-2SLS-IV \\
\hline
\end{tabular}

Notes: This table presents the results of panel data regressions with the random effects 2SLS-IV estimates of ROA on various governance mechanisms and control variables, considering also the impact of the financial crisis. $* \mathrm{p}<0.10, * * \mathrm{p}<0.05, * * * \mathrm{p}<0.01$. Robust standard errors are reported in parentheses. The null hypothesis for the Breusch-Pagan LM test is that variances across entities are zero $(\operatorname{Var}(u)=0)$. If the test is rejected at the 5\% level, it means there is a panel effect, and thus the OLS model is not appropriate. The null hypothesis for the Hausman test is the individual specific effects of the regressors are not correlated with the error term. If the hypothesis is not rejected at the $5 \%$ level it means that the random effect model is more efficient than the fixed effect model. The Durbin-Wu-Hausman test for endogeneity tests the null hypothesis that the variable in question is exogenous. A rejection of the null hypothesis implies that compared to an IV regression, the OLS is not an appropriate estimation technique, and that the variable in question should be treated as endogenous. In all models, time and industry fixed effects are controlled by the qualitative binary dummy variables. Table A1 provides the definitions of the variables. 
Table 6: The relationship between board structure and firm performance: country-level analysis without crisis interactions

\begin{tabular}{llll}
\hline & Tanzania & Kenya & Uganda \\
\hline Board size & $-0.011(0.051)$ & $-0.054^{* *}(0.022)$ & $-0.111(0.081)$ \\
Foreigners on the board & $-0.107(0.112)$ & $0.067^{* *}(0.033)$ & $0.146(0.219)$ \\
Civil servants on the board & $0.171^{* *}(0.085)$ & $0.092(0.058)$ & $0.069(0.145)$ \\
Education & $0.132^{*}(0.075)$ & $-0.009(0.050)$ & $0.299^{* *}(0.125)$ \\
Largest shareholder & $-0.084(0.135)$ & $0.005(0.022)$ & $0.170(0.176)$ \\
Foreign ownership & $0.076(0.092)$ & $-0.055^{*}(0.033)$ & $0.197(0.165)$ \\
Institutional ownership & $0.102(0.074)$ & $0.036^{* *}(0.016)$ & $-0.180^{* * *}(0.052)$ \\
Firm size & $-0.011(0.020)$ & $0.005(0.006)$ & $-0.016(0.045)$ \\
Sales growth & $0.041(0.078)$ & $0.118^{* * *}(0.025)$ & $0.181(0.121)$ \\
Leverage & $-0.408^{* * *}(0.073)$ & $-0.141^{* * *}(0.027)$ & $-0.220^{*}(0.110)$ \\
Constant & $0.271(0.187)$ & $0.134^{* *}(0.056)$ & $0.326(0.216)$ \\
& & & 37 \\
Observations & 93 & 352 & 4 \\
Number of firms & 9 & 34 & 0.766 \\
$\mathrm{R}^{2}$ & 0.792 & 0.296 & $30.22^{* * *}$ \\
F-test or Wald test & $32.01^{* * *}$ & $1069.27^{* * *}$ & 0.00 \\
Breusch-Pagan LM test $\chi^{2}$ & 0.00 & $163.84^{* * *}$ & NA \\
Hausman test $\chi^{2}$ & NA & 6.98 & 1.24 \\
Durbin-Wu-Hausman F-test & 0.49 & 1.31 & NA \\
First stage F-test & NA & NA & OLS \\
Method & OLS & $R E$ & \\
\hline
\end{tabular}

Notes: This table presents the results of panel data regressions with various estimates of ROA on various governance mechanisms and control variables. ${ }^{*} \mathrm{p}<0.10, * * \mathrm{p}<0.05, * * * \mathrm{p}<0.01$. Robust standard errors are reported in parentheses. The null hypothesis for the Breusch-Pagan LM test is that variances across entities are zero ( $\operatorname{Var}(\mathrm{u})=0$ ). If the test is rejected at the $5 \%$ level, it means there is a panel effect, and thus the OLS model is not appropriate. The null hypothesis for the Hausman test is the individual specific effects of the regressors are not correlated with the error term. If the hypothesis is not rejected at the 5\% level it means that the random effect model is more efficient than the fixed effect model. The Durbin-Wu-Hausman test for endogeneity tests the null hypothesis that the variable in question is exogenous. A rejection of the null hypothesis implies that compared to an IV regression, the OLS is not an appropriate estimation technique, and that the variable in question should be treated as endogenous. In all models, time and industry fixed effects are controlled by the qualitative binary dummy variables. 'NA' means not applicable. Table A1 provides the definitions of the variables. 
Table 7: The relationship between board structure and firm performance: country-level analysis with crisis interactions

\begin{tabular}{|c|c|c|c|}
\hline & Tanzania & Kenya & Uganda \\
\hline Board size & $-0.009(0.050)$ & $-0.059^{* *}(0.026)$ & $-0.230^{* *}(0.071)$ \\
\hline Foreigners on the board & $-0.080(0.110)$ & $0.069^{* *}(0.033)$ & $0.420(0.272)$ \\
\hline Civil servants on the board & $0.138(0.096)$ & $0.110^{*}(0.061)$ & $0.154(0.143)$ \\
\hline Education & $0.110(0.073)$ & $0.008(0.040)$ & $0.270^{*}(0.136)$ \\
\hline Largest shareholder & $-0.090(0.145)$ & $0.017(0.028)$ & $0.241(0.148)$ \\
\hline Foreign ownership & $0.100(0.079)$ & $-0.034(0.027)$ & $0.339(0.210)$ \\
\hline Institutional ownership & $0.119(0.086)$ & $0.049^{* * *}(0.015)$ & $-0.083(0.077)$ \\
\hline Firm size & $-0.012(0.020)$ & $0.004(0.005)$ & $-0.037(0.049)$ \\
\hline Sales growth & $0.064(0.074)$ & $0.111^{* * *}(0.020)$ & $0.003(0.121)$ \\
\hline Leverage & $-0.410^{* * *}(0.088)$ & $-0.126^{* * *}(0.027)$ & $-0.196(0.112)$ \\
\hline Crisis*Board size & $0.118(0.174)$ & $0.014(0.032)$ & $-0.010(0.449)$ \\
\hline Crisis* Foreigners on the board & $0.066(0.185)$ & $-0.060(0.043)$ & $-1.374(1.540)$ \\
\hline Crisis* Civil servants on the board & $0.955^{* *}(0.409)$ & $-0.052(0.071)$ & $4.590(4.224)$ \\
\hline Crisis* Education & $0.159(0.179)$ & $0.012(0.048)$ & $-3.122(3.008)$ \\
\hline Crisis* Largest shareholder & $0.779^{*}(0.418)$ & $-0.004(0.059)$ & $0.000(0.000)$ \\
\hline Crisis* Foreign ownership & $-0.040(0.152)$ & $0.003(0.055)$ & $0.000(0.000)$ \\
\hline Crisis* Institutional ownership & $-1.824^{*}(1.013)$ & $-0.026(0.027)$ & $0.000(0.000)$ \\
\hline Crisis dummy & $0.322(0.423)$ & $0.009(0.060)$ & $0.516(1.513)$ \\
\hline Constant & $0.238(0.168)$ & $0.142^{* *}(0.052)$ & $0.556^{* *}(0.194)$ \\
\hline Observations & 93 & 352 & 37 \\
\hline Number of firms & 9 & 34 & 4 \\
\hline $\mathrm{R}^{2}$ & 0.789 & 0.324 & 0.852 \\
\hline F-test or Wald test & $11.41^{* * *}$ & $670.70^{* * *}$ & $8.13^{* * *}$ \\
\hline Breusch-Pagan LM test $\chi^{2}$ & 0.00 & $164.23^{* * *}$ & 0.00 \\
\hline Hausman test $\chi^{2}$ & NA & 13.36 & NA \\
\hline Durbin-Wu-Hausman test & 1.05 & 0.91 & 1.63 \\
\hline First stage F-test & NA & NA & NA \\
\hline Method & OLS & $\mathrm{RE}$ & OLS \\
\hline
\end{tabular}

Notes: This table presents the results of panel data regressions with various estimates of ROA on various governance mechanisms and control variables, considering also the impact of the financial crisis. ${ }^{*} \mathrm{p}<0.10,{ }^{* *} \mathrm{p}<0.05,{ }^{* * *} \mathrm{p}<0.01$. Robust standard errors are reported in parentheses. The null hypothesis for the Breusch-Pagan LM test is that variances across entities are zero $(\operatorname{Var}(\mathrm{u})=0)$. If the test is rejected at the $5 \%$ level, it means there is a panel effect, and thus the OLS model is not appropriate. The null hypothesis for the Hausman test is the individual specific effects of the regressors are not correlated with the error term. If the hypothesis is not rejected at the $5 \%$ level it means that the random effect model is more efficient than the fixed effect model. The Durbin-Wu-Hausman test for endogeneity tests the null hypothesis that the variable in question is exogenous. A rejection of the null hypothesis implies that compared to an IV regression, the OLS is not an appropriate estimation technique, and that the variable in question should be treated as endogenous. In columns 1 and 3 the time effects and in all columns the industry fixed effects are controlled by the qualitative binary dummy variables. 'NA' means not applicable. Table A1 provides the definitions of the variables. 